\title{
Fasciitis complicating subcutaneous injection of interferon beta
}

Curtis L Cooper MD FRCPC, Rachel Gerstein RN, Kelly Kaita MD FRCPC

CL Cooper, R Gerstein, K Kaita. Fasciitis complicating subcutaneous injection of interferon beta. Can J Gastroenterol 2000; 14(Suppl B):81B-82B. Data pertaining to 65 patients treated at the Health Sciences Center Hepatology Research Unit in Winnipeg, Manitoba describing local complications related to subcutaneous interferon (IFN) injection administered to treat hepatitis $\mathrm{C}$ virus infection are presented. Nine patients experienced local erythematous reactions at the injection region. No life-threatening complications were identified. One case of fasciitis complicating IFN injection-a complication not previously reported - was successfully managed with surgical debridement and antibiotic therapy. This case is a dramatic example of why sterile technique during infections must be adhered to.

Key Words: Fasciitis; Hepatitis C virus; Interferon

\section{Fasciite compliquant l'injection sous-cutanée d'interféron bêta}

RÉSUMÉ : Nous présentons des données concernant 65 patients traités au Health Sciences Center Hepatology Research Unit à Winnipeg, au Manitoba, et décrivant des complications locales liées à une injection sous-cutanée d'interféron (IFN) administrée pour traiter une infection au virus de l'hépatite C. Neuf patients ont fait l'objet de réactions érythémateuses autour du site de l'injection. Nous n'avons identifié aucune complication menaçante pour la vie. Un cas de fasciite compliquant une injection à l'interféron- -une complication jamais signalée- a été traitée avec succès par débridement chirurgical et antibiothérapie. Ce cas montre de façon spectaculaire qu'il faut absolument maintenir une technique stérile lorsqu'on procède à des injections.
$\mathrm{H}$ epatitis $\mathrm{C}$ is a major public health concern of epidemic proportion. Several treatment protocols have achieved reasonably good results with interferon (IFN) alpha and ribavirin $(1,2)$. However, research continues in an effort to identify a highly effective treatment with minimal side effects. Subcutaneous injection of IFN is a relatively new therapy for hepatitis $\mathrm{C}$ virus (HCV) that has great potential (3). Although generally safe $(4,5)$, IFN has been recognized to cause local skin irritation on occasion. More serious local complications have not been described. We report a case of fasciitis complicating IFN injection.

\section{CASE PRESENTATION}

A 36-year-old HCV-infected man managed with daily subcutaneous IFN injections presented with a four-day history of progressively worsening left anterior-lateral tight swelling, erythema and pain associated with a temperature of $38.8 \mathrm{C}$, a white blood cell count of $7.6 \times 10^{9} / \mathrm{L}$ with a left shift and an erythrocyte sedimentation rate of $110 \mathrm{~mm} / \mathrm{h}$. His creatinine kinase level was $1246 \mathrm{U} / \mathrm{L}$, suggesting either compartment syndrome or myositis. An emergent computed tomography scan revealed diffuse subcutaneous swelling without gas extending from the left lesser trochanter to the knee (Figure 1).

Viral Hepatitis Investigative Unit, Department of Medicine, University of Manitoba, Winnipeg, Manitoba

Correspondence: Dr C Cooper, Division of Infectious Diseases, 501 Smyth Road, Room G12, Ottawa, Ontario K1H 8L6.

Telephone 613-737-8880, fax 613-737-8925, email cooper@ottawahospital.on.ca

Received for publication May 20, 1999. Accepted June 9, 1999 


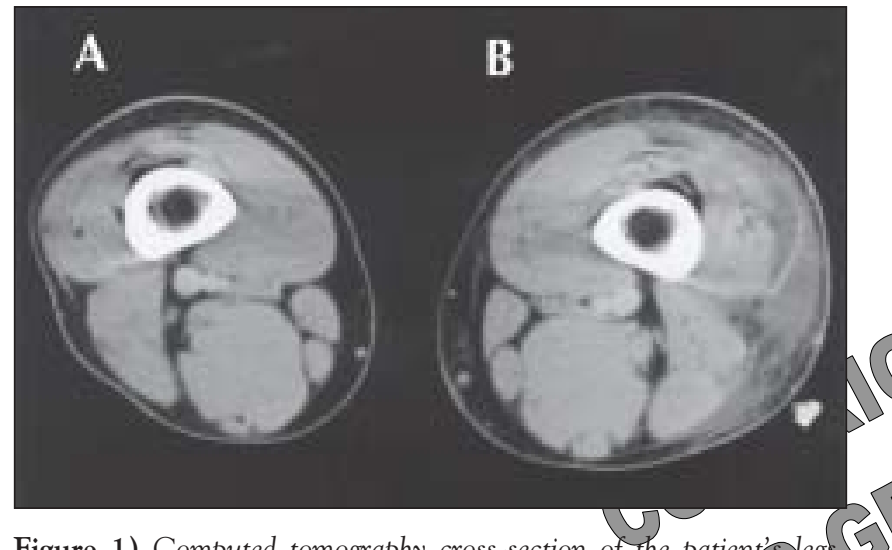

Figure 1) Computed tomography cross-section of the patient's legs. A Normal right leg; B Subcutaneous swelling left lateral tight with fluid collection (arrow)

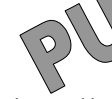

An ill-defined low density fluid collection measuring $5 \times 3 \times 8 \mathrm{~cm}$ was noted within the lateral aspect of the left tight in the region of the vastus lateralis. An additional collection was noted in the region of the tensor fascia lata extending to the lesser trochanter. Surgical exploration revealed small pockets of odourless, turbid fluid located between the fascial surfaces of healthy muscle. Frank pus was not observed.

Gram stain of the fluid revealed Gram-positive cocci in clumps subsequently cultured as Staphylococcus aureus sensitive to oxacillin (minimum inhibitory concentration [MIC] less than $0.5 \mathrm{~g} / \mathrm{mL}$ ), cefazolin (MIC less than $2 \mathrm{~g} / \mathrm{mL}$ ), gentamicin (MIC less than less than $1 \mathrm{~g} / \mathrm{mL}$ ), tetracycline (MIC less than $2 \mathrm{~g} / \mathrm{mL}$ ), trimethoprim-sulphamethoxazole (MIC less than 2/38 g/mL), clindamycin (MIC less than $0.25 \mathrm{~g} / \mathrm{mL}$ ) and vancomycin (MIC less than $2 \mathrm{~g} / \mathrm{mL}$ ). Blood cultures were negative.

Intravenous cloxacillin $2 \mathrm{~g}$ every $6 \mathrm{~h}$ was administered for two weeks, followed by four weeks of oral cloxacillin $500 \mathrm{mg}$ every $6 \mathrm{~h}$ for a diagnosis of $\mathrm{S}$ aureus fasciitis with compartment syndrome.

\section{DISCUSSION}

S aureus fasciitis following subcutaneous injection of IFN is a previously unrecognized complication of this treatment modality. A MEDLINE search failed to identify documented bacterial or chemical fasciitis complicating subcutaneous IFN injection. The presence of $S$ aureus in multiple surgical sites suggested against the diagnosis of chemical fasciitis with incidental culture contamination with skin organism. Culture of the powered IFN taken directly from the vial and the sterile normal saline used to reconstitute the IFN did not yield $S$ aureus, thereby ruling out injection product contamination. We postulate that $S$ aureus was introduced into the fascial plane as a result of poor cutaneous preparation of the injection site before injection. This was admitted by the patient. No further injection site complications were encountered in this patient following enforcement of strict hygienic measures including pre-administration showering and thorough cleaning with alcohol before injection.

A review of the 65 patients who have received IFN and IFN injections as part of clinical trials at our centre over the past eight years revealed no major life-threatening complications. No cases of deep structure infection such as bacterial fasciitis were identified; however, nine patients $(13.8 \%)$ developed erythema in the region of the injection, which resolved with discontinuation of the injections.

We have noted several potential risk factors for the development of local erythema including being female, dermal disease, sun exposure, venous insufficiency and failure to inject the medication deep enough. Reactions were more frequent in the first month of injections and in patients injecting daily versus those injecting three times weekly. Given the small numbers no statistically significant association could be identified.

\section{CONCLUSIONS}

We recommend as standard practice showering immediately before injection to avoid injection site infection. As with all subcutaneous injections, the area must be thoroughly disinfected with alcohol pads. Additionally, we advise patients to avoid pimples and cuts in the injection site. These simple precautions will avoid interruption in IFN therapy and prevent serious complications such as the one described above.

\section{REFERENCES}

1. McHutchinson JG, Gordon SC, Schiff ER, et al. Interferon alfa-2b alone or in combination with ribavirin as initial treatment for chronic hepatitis C. N Engl J Med 1998;339:1485-92.

2. Poynard T, Marcellin P, Lee SS, et al. Randomized trial of interferon alfa-2b plus ribivirin for 48 weeks or for 24 weeks versus interferon alfa-2b plus placebo for 48 for 48 weeks for treatment of chronic hepatitis C virus. Lancet 1998;352:1426-32.

3. Takano S, Satomura Y, Omata M. Effects of interferon beta on non-A, non-B acute hepatitis: a prospective, randomized, controlled-dose study. Japan Acute Hepatitis Cooperative Study Group. Gastroenterology 1994;107:805-11.

4. Perez R, Pravia R, Artimez ML, et al. Clinical efficacy of intramuscular human interferon-beta vs interferon-alphat $2 \mathrm{~b}$ for the treatment of chronic hepatitis. J Viral Hepatol 1995;2:103-6.

5. Castro A, Carballo E, Dominquez A, et al. Tolerance and efficacy of subcutaneous interferon-beta administration for treatment of chronic hepatitis C. J Interferon Cytokine-Res 1997;17:65-7. 


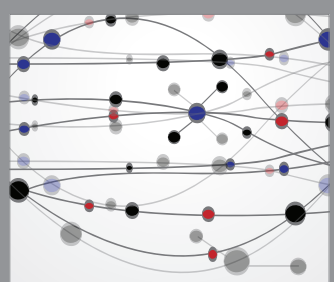

The Scientific World Journal
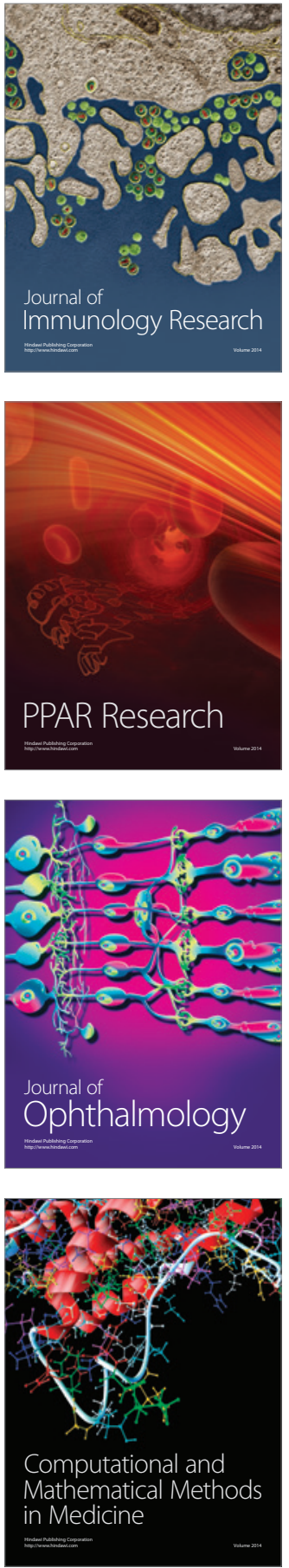

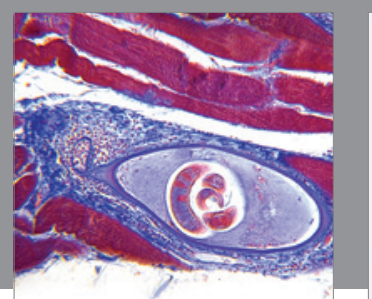

Gastroenterology Research and Practice

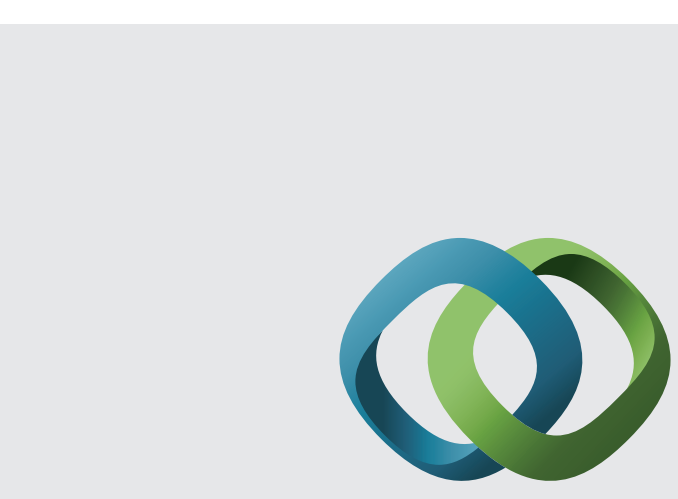

\section{Hindawi}

Submit your manuscripts at

http://www.hindawi.com
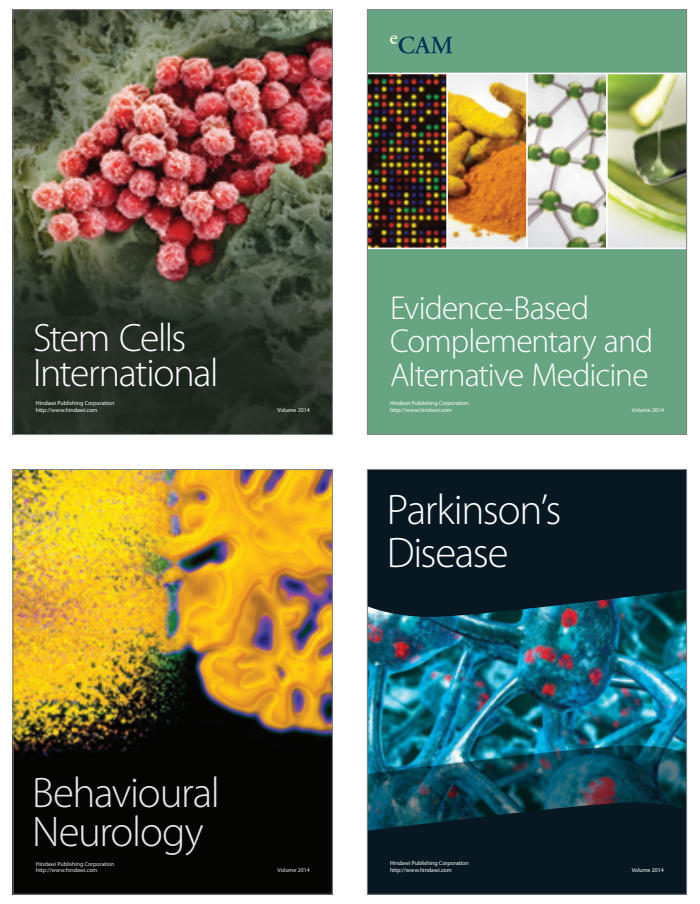
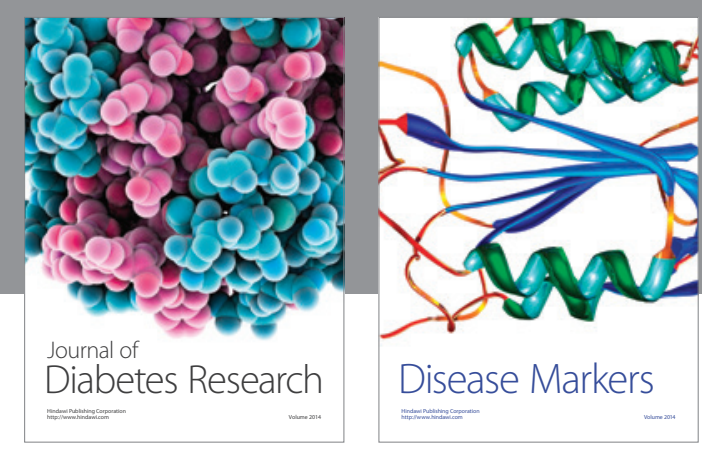

Disease Markers
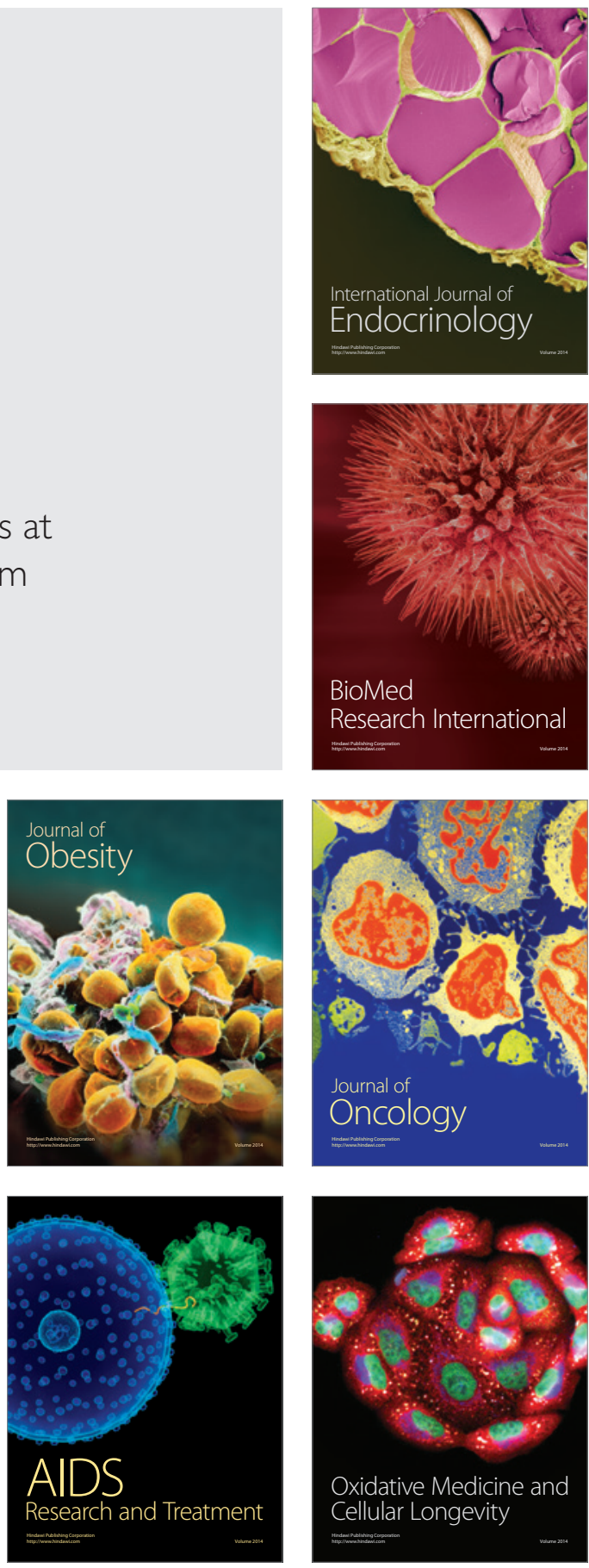